К. Г. Будажапова

А. С. Шагжеева

ВЫДАЮЩИЕСЯ ПРЕДСТАВИТЕПИ

БУРЯТСКОГО ДУХОВЕНСТВА

ДЫМБУ ПХАРАМБА И НИМБУ ПХАРАМБА

\author{
K. G. Budazhapova \\ A. S. Shagzheeva
}

\title{
OUTSTANDING REPRESENTATIVES OF THE BURYAT SPIRITUAL DYMBU LHARAMBA AND NIMBU LHARAMBA
}

Выдающиеся представители бурятского духовенства Дымбу лхарамба и Нимбу лхарамба были выходцами села Санага - крупнейшего поселения горной Закамны. Ее географическое положение на границе с Монголией сказалось на составе населения. Здесь проживали коренные жители Санагинской долины, прибывшие с берегов Ангары для несения караульной службы представители западных родов - шошологи и хонгодоры, а также представители русского казачества, несущие караульную службу. Это обусловило своеобразие культурного развития Закамны в XIX в. на стыке трех религиозных, культурных и образовательных традиций: шаманской, буддийской и православной. Шаманская культура была представлена сохранившимися шаманскими обрядами, верованиями и огромным запасом их фольклора, обрядовых праздников и поверий, буддийская культура - дацанами. На территории Закамны действовали Санагинский, Бургултайский дацаны и Бортойский дуган. Прочно входило в закаменскую социокультурную среду и третье направление культуры - русское православное. В Санаге успешно функционировали русско-монгольская инородческая школа для сыновей казаков и небольшая православная церковь (часовня) в русском Ключевском карауле, который населяли русские казаки Вагановы, Аристарховы, Ловцовы, Жарковы, дома которых сохранились до сегодняшнего дня.

Начало деятельности Санагинского дацана пришлось на 1820 год. Он был построен в долине Номтогол (долина знаний). Задолго до его строительства в 1786 г. в этой местности был построен первый буддийский дуган (молельный дом). Санагинский дацан стал одним из крупнейших дацанов Бурятии. «Число лам в годы расцвета буддизма достигало 700 человек. Дацан располагал полным собранием тибетского канона «Ганджур» и «Данджур» в 1 тыс. томов; он был в числе немногих дацанов, где проводились мистерии Цам. Сюда на хуралы приезжали и приходили пешком жители с территорий, где сейчас расположены Окинский, Тункинский, Закаменский районы, а также из Хубсугульского района

Будажапова Клавдия Гомбоевна - ветеран педагогического труда, краевед.

Шагжеева Арюна Спиридоновна - студентка 4 курса юридического факультета Федерального государственного автономного образовательного учреждения «Российский университет дружбы народов» (г. Москва, Россия). 
Монголии» [Энциклопедия буддизма: эл. ресурс]. На территории дацана действовали: Чойра-дуган $(18 \times 24)$, Цогчен-дуган, Жуд-дуган, Диваажин-дуган, Номой-дуган $(8 \times 8)$ - библиотека, Майдари-дуган, Мамбын-дуган, Дуйнхор-дуган, Цанид-дуган, Маанин-дуган, Линхын-дуган.

Особо следует отметить Мамбын-дуган, в котором вели прием ламы-лекари. Ламы санагинского дацана был искусными врачами. Их мастерство в лечебном деле было известно далеко за пределами Закамны. Особой известностью пользовались маарамба Даржаа и его сыновья Дагба и Догдон. Большой популярностью среди населения пользовался Дуйнхор-дуган. Здесь летом исполнялась мистерия Цам, которую проводили не все дацаны Бурятии. Первая мистерия Цам в Санагинском дацане состоялась при настоятеле Зоохэйн Габжа в 1842 г. [Там же]. В Цанид-дугане происходили философские диспуты.

Открытие дацана стало знаменательным событием не только для санагинцев, но и для населения верхней зоны Закамны. С этого времени началось обучение грамотности ламами, широкое внедрение в социокультурные реалии того времени буддийских ценностей. В дацане несли службу ламы-просветители, внесшие большой вклад в развитие родного края.

Не претендуя на полноту освещения, мы попытаемся рассказать о просветителях Санаги, которые стояли у истоков просвещения жителей края. Это двоюродные братья из рода шошолок, подрода эрхэтэн Дымбу и Нимбу лхарамбы, которые получили это самое высшее духовное звание (доктора философии) в Тибете. По словам старожилов и из газетной статьи в «Буряад Унэн», в далеком Тибете, когда они держали шойро-научный диспут между сильнейшими хубилганами (учеными ламами) всего буддийского мира, они обращались с молитвой о покровительстве к священным уулам - горам родной Санаги и с честью выдержали экзамен.

Во время сбора материала для статьи авторы столкнулись с определенными трудностями: было мало сведений, практически отсутствовали публикации. Пришлось буквально по крупицам собирать сведения у старожилов Санаги и в музее, затем обобщать и систематизировать собранный материал, начиная с 90-х гг. прошлого века. Неоценимую помощь в свое время оказали: ученик Нимбу лхарамбы Гомбоев Ширап Цыденович - бывший хуварак Санагинского дацана, сооромбо; Унтанов Даши-Дондок Азраевич - бывший лама, экстрасенс, ясновидец, подполковник КГБ в отставке, участник ВОВ, кавалер орденов боевого Красного Знамени, Красной Звезды, Отечественной войны 1-й степени и многих медалей; Унтанова Долгор-Цырен Юмдэлыковна - племянница лхарамб; Бабалаева Цыренбал Жамсарановна. В 1999 г. в газете «Буряад Унэн» вышла статья «Выдающиеся ламы-ученые из Закамны» Дагбы Шагдурова - кандидата исторических наук, нашего земляка-закаменца из Дархинтуя. В 2002 г. вышла книга первого ширетуя вновь возрожденного дацана Зундуева Ринчина Дулмаевича. Из этих источников и родословного древа рода шошолок вырисовывались образы ученых лам. 
Летом 1874 г. в местности Байдалша на берегу речки Дэргуна у подножия горы Баян-Зурхэн, что на северо-востоке Санагинской долины, в семье Гунзена родился средний сын Дальбаа (впоследствии Дымбу лхарамба). В этой живописной местности расположился летник Гунзена, одного из самых состоятельных людей Санаги. Люди подрода эрхэтэн стремились к просвещению, из них вышли и ламы равного ранга и звания (лекари, художники-иконописцы, заклинателилуйжанши, философы), а также учителя местной русско-монгольской школы для сыновей казаков, к примеру Юмдэлэхк Балданов (Ешэ хувархай), который имел самодельное печатное оборудование (бар), на котором выпускал детские дидактические пособия, сказки, поучения на старомонгольском языке. Юмдэлэхк Балданов одно время обучал детей в долине Тутхалта.

Вот имена лам из подрода эрхэтэн:

1. Дымбу-лхарамба (философ)

2. Нимбу-лхарамба (луйжанша, философ)

3. Лошон-аграмба(заклинатель)

4. Ламажап-габжа (лекарь)

5. Ринчин-Дондок-лама (лекарь), учился в Санкт-Петербургском медицинском институте

6. Сультим-лама

7. Гэндэн-Жамса-лама

8. Арьяндаб-лама

9. Жалсап-лама

10. Лудэп-лама (художник)

11. Аюша-лама

12. Монлам-лама - второй ширетуй вновь возрожденного дацана, депутат райсовета.

Санагинский дацан для Дымбу и Нимбу явился первой ступенью в мир знаний. Затем Урга (Богдын хуреэ), и наконец как особо отличившихся учеников их направили в страну гор и снегов Тибет (Баруун Джу). Рассказывают, что когда их провожали до перевала Сагаан Бэлшэр, мать Дымбу дала сыну на прощание оглушительную пощечину, чтобы он не скучал по дому. Это не означало, что она не любила сына, просто желала, чтобы он все свои помыслы посвятил учебе. В то время это было неординарным поступком для женщины-бурятки из глухого села. Они добирались до Лхасы на конях, шли пешком, когда кони уставали. В далеком Тибете ламы из Санаги отличились широкими и глубокими знаниями, за что получили имена Дымбу (солнце) и Нимбу (луна) - в переводе с тибетского. В Лхасе они учились почти 30 лет. Нимбу тайно выехал из Тибета и в 19261928 гг. был шэрээтэ (настоятелем) Санагинского дацана, учил молодых хувараков, проводил наиболее сложные обряды. В 1930 г. был арестован и увезен в Иркутскую тюрьму, где вскоре скончался. В то время сталинское руководство страны начало репрессии, т. е. карательные меры против религии, богатого и среднего сословия, казаков и руководителей, ученых, деятелей образования, кто был прямо или косвенно не согласен со Сталиным. А Дымбу лхарамба жил в Лхасе и 
продолжал служить буддийской религии до 1960-х гг. Был учителем Далай-ламы XIII и выдвинут на высокую должность Гандан-Тубаан-ламы Баруун Джу, где с ним соперничали видные хубилганы (перерожденцы). По имеющимся сведениям, он только 1 раз, в 1925 г., приезжал на родину. Ему тогда было около 30 лет. Хурал Майдари собрал сотни и тысячи людей со всей Закамны, Джиды, Тунки, Селенги и соседнего Булганского аймака Монголии. Такого грандиозного хурала до этого и после не было (Шагдуров 1999).

За Гунзенэй Дымбу в Тибете был установлен строгий надзор, чтобы он не выехал за пределы страны и не унес тайные и сокровенные знания. Но он уехал тайно и все равно вернулся в Тибет, ибо предчувствовал надвигающиеся репрессии против служителей религии. Нимбу же был страстным патриотом и ни за что не хотел покидать родину.

Бывший шэрээтэ Санагинского дацана Монлам имел возможность посетить Тибет, когда был послушником Санкт-Петербургского дацана, и поклониться буддийским святыням, в том числе и субурге Дымбу лхарамбы, где покоится его прах, и сделать фотоснимки. В своих впечатлениях от посещения Тибета он пишет, что первое, что бросается в глаза, - это местность, которая напоминает Закамну и Тунку, с той лишь разницей, что там меньше леса и климат мягче. В Брайбун-монастыре находится Гоман дацан, где прежде традиционно обучались ламы из Бурят-Монголии. Монлам-лама происходит по матери из эрхэтэн (правнук Юмдэлэка Балданова), является родственником двух лхарамб и продолжает их дело.

В 1931 г. было надумано «Санагинское дело» о вооруженном восстании ламско-кулацкой верхушки населения против Советской власти. Были осуждены невиновные люди, которых бросили в тюрьмы, отправили в ссылку в дальние края, разлучили членов семьи, отобрали имущество и скот. В районе были разрушены Санагинский и Бургултайский дацаны, Мыло-Бортойский дуган [Архив ФСБ Бурятии. Д. 6460].

По этому надуманному делу Санага потеряла своих лучших и образованных людей, крепких хозяев. В советское время потомков этих людей не допускали на руководящую работу, не разрешали выезд за границу, они не удостаивались высоких правительственных наград, за ними было клеймо детей врагов народа.

В связи с демократизацией российского общества произошла реабилитация репрессированных, возрождаются национальные культуры и религии, восстанавливается связь поколений, хотя говорить о том, что она возродится в прежнем виде, трудно. Но тем не менее налаживаются связи с буддистами многих стран Индией, Непалом, Бирмой, двумя Кореями, Японией, Китаем.

Мы имели возможность беседовать с высочайшим Еши-Лодой римпоче из Тибета во время его пребывания в Санагинском дацане. Он с большим уважением отозвался о Дымбу лхарамбе. Сегодня необходимо не забывать и помнить имена наших знаменитых духовных просветителей - Гунзэнэй Дымбу лхарамбы и Шоеной Нимбу лхарамбы, прославивших свой родной край в далеком Тибете и достигших больших высот в буддийской иерархической ступени. 


\section{Источники и питература}

Архив ФСБ РБ. Д. 7074. Л. 8; Д. 6460.

Батуев Б. Неизвестные страницы истории Бурятии / Б. Батуев, Б. Базаров, С. Очиров, Д. Н. Раднаев. - Улан-Удэ, 1992.

Доржиев Б. Как в Закамне закрывались дацаны / Б. Доржиев // Правда Бурятии. 1992. - 29 марта.

Зубакин А. Знать и помнить / А. Зубакин // Знамя труда. - 1989. - 23 марта.

Зундуев Р. Д. Санага-Булагай Даша-Пунсэглинг хиидэй туухэ / Р. Д. Зундуев. - Закаменск, 2002.

Шагдуров Д. Выдающиеся ламы-ученые из Закамны / Д. Шагдуров // Буряад Унэн. 1999. - 20 мая.

Ринчинов Ц. Ц. Санагын сэгнэшэгуй баялигьаа / Ц. Ц. Ринчинов. - Закаменск, 1995.

Энциклопедия буддизма [Электронный ресурс]. - Режим доступа: http:// vbuddisme.ru/wiki/Санагинский_дацан.

\section{Информанты}

1. Гомбоев Ш. Ц. - бывший хуварак Санагинского дацана.

2. Унтанов Д.-Ц. А. - подполковник КГБ в отставке, бывший хуварак.

3. Унтанова Д. Ю. - родственница лхарамб.

4. Бабалаева Ц. Ж. - жительница села Санага.

5. Монлам-лама - бывший шэрээтуй Санагинского дацана, депутат райсовета.

6. Унтанов Р. Б. - ветеран педагогического труда.

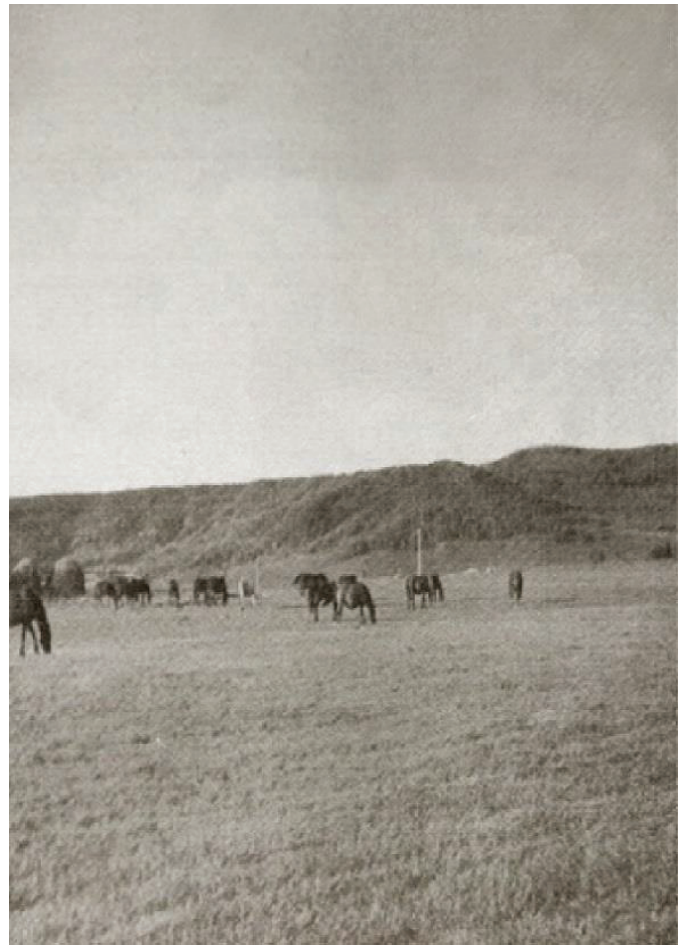

Местность Байдалша, где родился Нимбу лхарамба 

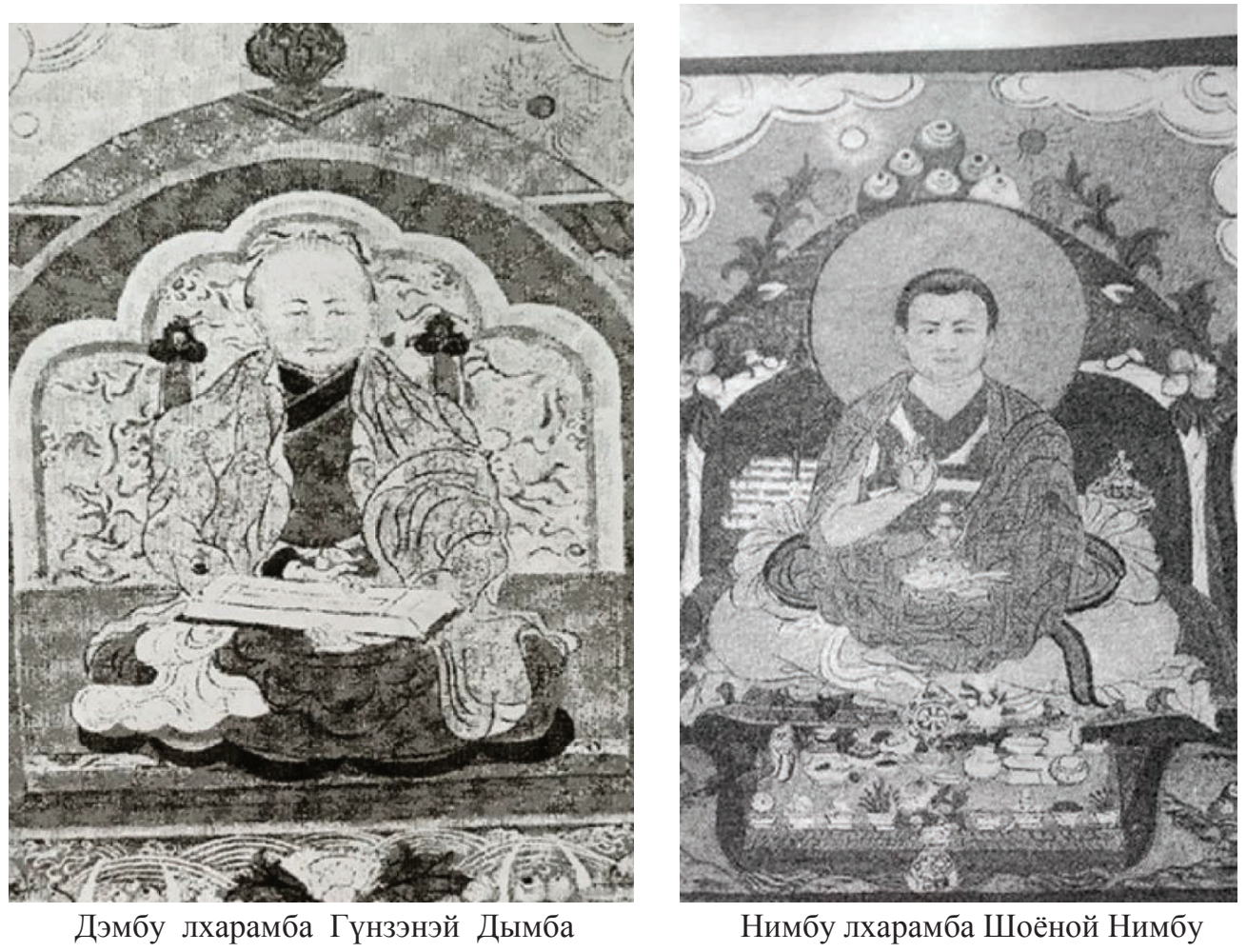

Нимбу лхарамба Шоёной Нимбу

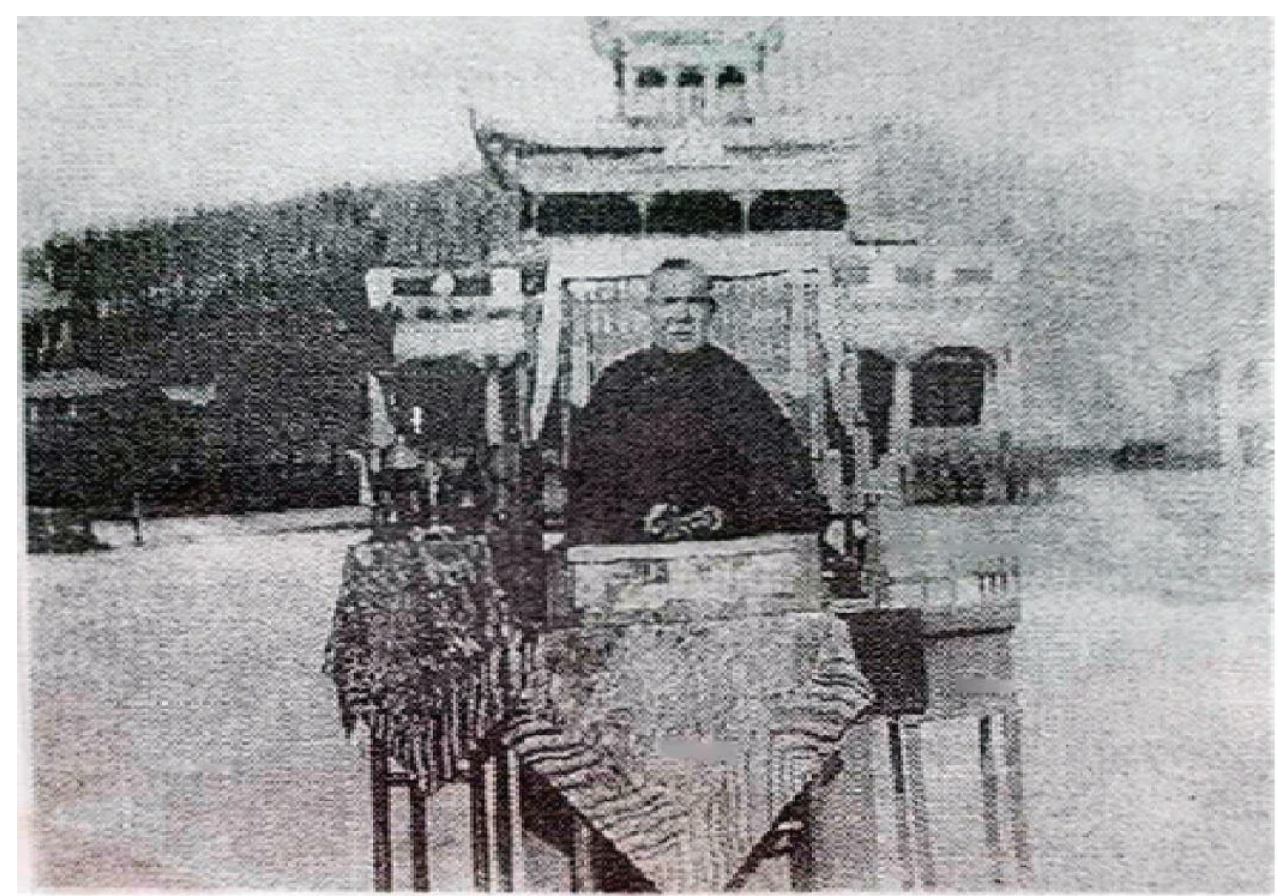

1928 г. Нимбу лхарамба - настоятель Санагинского хурэ 